\title{
The Mapping of Center and Periphery, and the Geography of Otherness
}

Jonathan Locke Hart

Shandong University, Weihai, School of Translation Studies, 180 Wenhua Xilu, Weihai, P. R. China 264209 (also University of Toronto/Harvard)

https://orcid.org/0000-0002-2518-5123

jonathan_hart@harvard.edu

Some literatures, like Canadian literature, may be considered minor because Canada is not a major power. But in reality, Canadian literature and other literatures, large or small, are part of a cultural history that is not merely local or even national, but international. The territories of culture and literature in literal or metaphorical terms shift over time. Using a comparative method, this article examines texts-such as The Saga of Eric the Red and works by Columbus, Verrazzano, Jeannette C. Armstrong, Marie Annharte Baker and Carrie Best-to demonstrate the shifting boundaries of time and space and to explore the connections between cultures and literatures in Canada, Europe and the Atlantic and international worlds as part of a longstanding globalization. The article demonstrates that the hybridity resulting from cross-cultural contact and colonization typically blurs the distinction between center and periphery, revealing the historical fluidity of the political boundaries on which the concepts of national and world literatures are based. In doing so, it focuses on how North America, particularly Canada, and the historical process of its discovery, settlement, and colonization have connected this region to other parts of the world.

Keywords: literature and geography / Canadian literature / center / periphery / cultural identity / otherness / hybridity / globalization

\section{Introduction}

Some literatures, such as Canadian literature, may be seen as a small or minor literature because Canada is not a great power. But in fact, Canadian literature and other literatures, supposedly major or minor, are part of a cultural history that is more than local or even national but are international. The territories of culture and literature in literal or metaphorical boundaries shift over time. This literature is part of 
world literature, just as the islands of the Caribbean may be small but their literatures and cultures are connected to a wider history and have international and world connections. In other words, their space and culture are small and big at once, local and not. For instance, Derek Walcott, Dionne Brand and Phillis Wheatley are all connected even if they wrote at different times and in different spaces (in St. Lucia and in the territory that is now the United States and Canada). The boundaries, cultural, political and social, of a minor or middling territory such as Canada are inextricably connected to its neighbor, the United States, which was once peripheral and not central, more minor than major. Canada itself could be called minor or peripheral but, for some time, it has, despite its smaller population, been a key part of the French and British empires and since the Second World War one of a half dozen or dozen or so economic powers.

Languages and literatures experience centrifugal as well as centripetal forces. The center and periphery in maps depend on vantage or point of view, where the cartography is framed or centered. In terms of space and time, of the boundaries we use to carve up the earth, the territories I discuss here are actual and metaphorical as they inhabit culture and are not natural boundaries like rivers. The boundary between Canada and the United States on the Prairies is entirely geometrical along the Forty-ninth Parallel. This border can seem arbitrary and families can live on both sides of a mutually agreed line for European settlers, but not necessarily for indigenous peoples who had crossed that line for hundreds and thousands of years before it was drawn. Perspective is part of territory and that perspective has to do as much with the observer in time and spaces as what is being viewed.

My interdisciplinary approach to territories involves different disciplines surrounding literature, culture and history but also depends on geography in actuality but also in metaphorical and conceptual ways. Regions can be parts of states or countries and continents depending on point of view. In a global sense North America is a region. The regional can also inhabit the liminal space between the local and the global as well as complicate the national. For instance, the Prairies are a region as the Great Plains go from Mexico well into Canada and include a vast part of the United States. The national boundaries do not erase the shared experience of life on the Prairies and the national boundaries of New Spain (later Mexico), the Spanish, British colonies and the French colonies (in what is now the United States and Canada) affect the cultural territory, representation and self-representation of literature, history and geography. Nothing is static in geography, his- 
tory and culture (including literature). Globalization, which has always been there but is intensifying, provides changing perspectives on territory and related concepts.

These global alterations prompt explorations of understanding, recognition and evolution in regional realities in the world beyond the idea of the nation state. This article provides a critical perspective that may help to understand the changes that one culture and literature from Canada can tell us about new spaces opening up over time for the making and reception of literature and culture. This work will provide a wider context too and show, through a comparative view, how the local, regional and national are also global and that the global is made up of smaller parts.

The article examines how center and periphery modify each other, examining texts from the expansion of Western Europe and how Africa, the New World, Asia and elsewhere affect the mapping of cultural and literary texts, what I have called elsewhere the geography of otherness. Here the "other (l'autre)" is spatial and temporal and the self and other meet in a liminal space or threshold between cultures, languages and literary, travel and related works, so the sense is more particular than that expressed by theorists such as Derrida, Kristeva and Lévinas (Derrida, Marges; Derrida, Psyché; Kristeva; Lévinas). My geography of otherness might also be seen, in Gaston Bachelard's terms, as a poetics of space, although extended into liminal cultural and literary spaces in my own specific ways, bringing together otherness and space in relation to self or one's language and culture (see Bachelard; Chimisso, Gaston Bachelard 14; Chimisso, "Gaston Bachelard's Places" 183-195; Alison). The root of other, with cognates in various German languages, appears to come from the Indo-European base of Sanskrit anya and relates to the Latin alter, the Indo-European suffix "originally having a spatial sense, expressing the contrast between two or more things with regard to their location" (The Oxford English Dictionary), suggesting a poetics of space as well as a poetics of time (Hart, The Poetics 1). For instance, the texts of travelers, explorers and missionaries like Marco Polo, Columbus, Matteo Ricci and others but then the descendants of Native Americans like Garcilaso de la Vega and Jeannette Armstrong, Africans such as Phillis Wheatley and Equiano and Asians like Joy Kogawa and Michael Ondaatje all question center and periphery, us and other.

The role of go-betweens or mediators-such as Gonzalo Guerrero, Jerónimo de Aguilar, La Malinche, Tisquantum (Squanto) and Étienne Brûlé in the sixteenth and seventeenth centuries—also complicate these 
cultural and textual maps, so that so-called cultures and literatures of the periphery affect those at the so-called center (Europe in this case). These mediators are European and indigenous and are part of the histories of Mexico and Central America, Mexico, the United States and Canada and their ambivalent position helps to create new cultures that involved a meeting of Native and European cultures. New hybrid cultures are being born at this time. Hybridity and shifts in perspective and power affect this mapping of space and culture. Canada or any of the other territories involved (with their changes over time and their altered names, borders and mapping) are part of a context and cannot be seen entirely on their own.

The same is true with the United States, which expanded from the Thirteen Colonies founded by England and part of the British Empire. The colonies were, after the end of the Seven Years War (1756-1763), ever so briefly part of British North America with New France (now Quebec), Nova Scotia and the like in what came to be called Canada. The United States broke with Britain through revolution, whereas Canada became independent through evolution in 1867. Families live on both sides of the border. Two nations were made of a common culture and language in English and French settlers also ended up living on both sides of this border. Hawaii only became a state in 1959. These nations and cultures were and are works in progress. Parts of the United States - parts of Maine, Washington State and Oregonused to be parts of British North America (what we now call Canada). The United States also absorbed parts of New France and New Spain, anglicizing the French and Spanish colonies. Saint Louis is a French name, Los Angeles a Spanish one. Yet, out of many one, means that an English only movement tries to prevent minority languages from thriving. So the major culture and literature of the United States-which used to be colonial and minor or peripheral is no longer, as in time and history it became major and colonizing - is not so different from English Canada, which is less minor than it was in literature and culture but which is a middle power and not a world power.

Americans and Canadians speak forms of "American" English, that is English in the Americas. People from other parts of the world might confuse them when they speak. But each state has tried to differentiate itself from the mother country, despite speaking English, a mixture of Anglo-Saxon (a Germanic language) and western French or Norman. Americana and Canadiana grew up, so John Smith and Jacques Cartier, part of the history of English and French expansion respectively, become origins of the American and Canadian states 
and their cultural, literary and historical apparatus. The Franks and the Normans were the only Germanic groups in northwest Europe to speak a Romance language-a form deriving from Latin—called French. Canada got French and English from these Germanic tribes, and English Canada and the United States share English (with about 28 percent of the words from Norman French) and although having accents and markers from England, they work to make their own cultures and literatures. Unless one were a linguist, would it be possible, if the place names were left blank to know whether a literary work were British, Irish, Canadian, American, Australian, New Zealand and so on? So much effort has gone within each state and among these countries to make distinctions for national identity and pride. There is always internal colonization as well as external colonization in empires and even in nations from center to periphery.

The central argument of my article is that history, language, trade and culture break down or blur the political boundaries that are built up. Time changes what people desire to be unchanging. Nation building is also a matter of unbuilding. In Britain, the suppression of the Celtic languages - such as Cornish, Scottish and Irish Gaelic, and Welsh—spoken by inhabitants there before the Germanic invasions (not to mention Latin in England as it was a Roman colony for a time), shows the cultural and linguistic politics of language and the stories told in it - what we now consider to be literature, a term that had different meanings before (see Miller). The French had a number of languages in the boundaries of what is now France, including Breton, the Celtic language of Brittany (little Britain) that seems to have come from Britain. England (later Britain) and France were the founding European states of what is now Canada.

The linguistic politics of Canada, the divide between French and English, appears deaf and ignorant to the relation of English to German and French, or at least, to shift metaphors, turns a blind eye to those relations. In the United States, at one point, there was a push, in some quarters, to call American English "American." How could a new empire speak the language of the old empire it had rebelled against? This was not like Greece and Rome in that way despite the myth of the westward movement of empire or translatio imperii or the translation of empire (see Hartman 214; Hart, Empires). The Anglo-American settlers were generally not happy when Britain protected the French language and the Catholic church with the Quebec Act of 1774. Their ancestors had been Catholic and some of them had spoken some form of French or a new language made of forms of French and German, but that does 
not seem to matter in matters of building nations and empires. In fact, even as Latin was the language of educated Europe and its colonies, those who knew the language were suppressing forms of vulgar languages derived from Latin or Romance languages, Spanish and French, in North America. Shakespeare had probably gone to school in Greek and Latin and uses French in Henry $V$, but Shakespeare could be used to promote English/British nationalism and empire and even the dominance of English in Canada and the United States (see Baldwin). The Americans found English around the world when they expanded their power and strengthened that further.

But in Canada and the United States, as there had been in Britain with the pre-Celtic and Celtic peoples and their cultures and languages, there was an attempt at replacement. English came to dominate for quite some time and was part of an effacement and even destruction of indigenous peoples, cultures and languages. These people did not make and do not accept the boundaries, the territories, of Canada and the United States. Indigenous peoples question the making of such nations and many now raise their voices and many also do so in English, French and Spanish in North America. Languages and stories contain different points of view even if they try to efface or destroy other ones. Indigenous peoples interpret Columbus and colonization in different and even opposing ways to those in settler cultures and there was soon and is now a hybrid or mixed culture, which complicates matters further (Hart, Columbus). Just as there were bilingual texts in Norman England, there are in North America, sometimes between European and indigenous languages (see McIlwraith). We might speak about different cultural registers within a territory and even within the mapping of English as a language (or any other language). We understand that Canadian and American literatures exist but we can see how porous or centrifugal they are in relation to history, boundaries, language and culture. They also co-exist.

Times change and sometimes there are ironies in those changes or developments. Native and settler views can differ on origins. East Asians may have emigrated to North America where others may have come from Asia thousands of years before some of the challenges of climate change (Beringa is under water) (see Moreno-Mayar et al.; Raff). Americans throughout the Americas were not from Europe, but Europeans and their descendants tried to define what it was to be Spanish, Portuguese, English, French, Dutch "Americans." Joy Kogawa and Fred Wah in Canada and Marilyn Chin and Maxine Hong Kingston meet Buffy Sainte-Marie, Tom King and Jeannette 
Armstrong in the border crossings of American and Canadian cultures and literatures that are new for the recent arrivals but far from it for the indigenous peoples. Seeking Asia in Canada and the United States was and is a complex matter.

National literatures may be necessary practical categories, but the idea of territories and boundaries has been shifting, and one can see this when discussing Canada and the United States and adjacent areas such as the Caribbean and other neighbors in the Americas. Over time and with trade and cultural exchange, including media and the internet, such territories and their boundaries are more porous. Culture and literature are local and global with liminal regional and national spaces between. The Vikings moved westward and each settlement was itself but part of a Norse concatenation, trading pattern, cultural network. Columbus sought Asia and found the New World with peoples who, in his texts, he claimed were Asian. The reverberations of Columbus' landfall were felt in the New World, including in Canada, and of course globally in time. The indigenous peoples of the Americas and the Africans brought as slaves as well as the mixed cultures with Europeans in the New World (Canada included) helped to create new hybrid cultures. These cultures and literatures often crossed political boundaries that Europeans and European settlers helped to draw.

In what follows, the article will discuss the Norse settlements and the connection of the their colony in what is today Canada within a wider context, including its neighbor, Greenland; examine the European seeking of Asia from Columbus onward and the more recent settlement of Asians in the Americas; Natives in the New World; Africans in the Americas; all including Canada. Owing to space, the closer analysis will involve one or two texts or a few works in each of the four sections.

\section{Westward by Sea: Greenland, Canada and the Norse Context}

Particular works give us a sense of the geography of the texts, and this geography is not so readily national, as in Canada or the United States, minor and major. Canada was not always Canada (it was called, in part, New France) and there was no United States until the 1770s and 1780s (officially in 1783). The Norse in their sagas mention Greenland and Vinland (apparently in Canada).

The texts of canons of a given literature or even a culture are subject to the centripetal forces of myth-making and identity and the centrifugal forces of context and porous borders. This challenge to iden- 
tity occurs through historical, cultural, linguistic and other changes in the same territories. For instance, "Canada" did not exist as a word to describe the territory it now holds even in 1948 let alone 1048 . The Norse or Vikings were in Newfoundland, as the archeological evidence proves, and Newfoundland did not join Canada until 1949. The Norse had settlements in adjacent Greenland and beyond and so there was a bond in trade and culture that broke down any boundary for Norse culture among the settlements. Part of what is Canada was part of Norse expansion and has connections with Iceland, Scandinavia, Ireland, the Danelaw in England, Normandy and elsewhere. The Norse texts describing Greenland and Vinland and the settlement in what is now Newfoundland are claimed for Canada's history, literature and culture but are an aspect of a wider Norse history, culture and literature, an aspect of Europe and the Atlantic world.

Greenland was part of a Norse expansion into Normandy, Ireland, Iceland, Kiev, Sicily and elsewhere. It was from Greenland that the Norse expanded into Newfoundland (Canada). Religion played a role in the exploration of the Americas. Leif Ericson, like Columbus later, brought Christianity to the new lands (Greenland). The saga of Vinland says as much about Leif: "He soon proclaimed Christianity throughout the land, and the Catholic faith, and announced King Olaf Tryggvason's messages to the people, telling them how much excellence and how great glory accompanied this faith." ("The Saga" 36) Leifs father Eric held more to the pagan religion, so had not brought Christianity to Greenland (36-37).

The Dorset people were the original peoples of Greenland and in the tenth century the Norse arrived and, later, the Inuit. The mixing of peoples or even the conflict between or among them challenges any ready sense of identity, cultural, historical, national or literary. Tim Folger brings to light some of the most recent research on Viking settlement in Greenland, its origins, economy and disappearance in the generation or so before Columbus's landfall in the western Atlantic. Folger notes: "Some believe that the Norse, faced with the triple threat of economic collapse, pandemic and climate change, simply packed up and left. Others say the Norse, despite their adaptive ingenuity, met a far grimmer fate." (Folger) How the settlement in "Canada," which was established from Greenland, ended is also an open question.

The encounter between Viking settlers and local inhabitants is part of the experience in this exploration and settlement in Newfoundland from the base in Greenland. The saga of Vinland describes this first contact between the indigenous peoples and the Norse: 
Now one morning early, when they looked about them, they saw a great number of skin-canoes, and staves were brandished from the boats, with a noise like flails, and they were revolved in the same direction in which the sun moves. Then said Karlsefni: "What may this betoken?" Snorri, Thorbrand's son, answers him: "It may be, that this is a signal of peace, wherefore let us take a white shield and display it." And thus they did. Thereupon the strangers rowed toward them, and went upon the land, marveling at those whom they saw before them. They were swarthy men, and ill-looking, and the hair of their heads was ugly. They had great eyes, and were broad of cheek. They tarried there for a time looking curiously at the people they saw before them, and then rowed away, and to the southward around the point. ("The Saga" 47)

The Vikings see the canoes of the indigenous peoples, who are strangers to them, and they try to guess the signs of the brandished staves that sounded like flails. Karlsefni wonders what the staves mean and Snorri thinks they might be "a signal of peace" and suggests that they take their own maker of peace, "a white shield." The narrative makes it seem as though the Natives marvel at the Vikings while the Norse consider them dark, "ill-looking" with ugly hair with big eyes and broad cheeks. The Norse do not marvel but see the others "marveling" at them and "looking curiously" at them, until they row away. Here is cultural difference and high self-regard in a territory with two groups of different peoples on it and coming across each other for what appears to be the first time.

Besides otherness and difference in appearance and signs, there are distinctions between the animals and material practices of the two cultures:

Karlsefni and his followers had built their huts above the lake, some of their dwellings being near the lake, and others farther away. Now they remained there that winter. No snow came there, and all of their live-stock lived by grazing. And when spring opened, they discovered, early one morning, a great number of skin-canoes, rowing from the south past the cape, so numerous, that it looked as if coals had been scattered broadcast out before the bay; and on every boat staves were waved. Thereupon Karlsefni and his people displayed their shields, and when they came together, they began to barter with each other. Especially did the strangers wish to buy red cloth, for which they offered in exchange peltries and quite grey skins. They also desired to buy swords and spears, but Karlsefni and Snorri forbade this. ("The Saga" 47)

The Norse brought their livestock with them. They were farmers and hunters (especially of seals) in the New World and traded tusks in the ivory trade in which the Vikings were involved (Star et al.). The Vikings 
seem outnumbered as the poetic description of the canoes being so many they were like coals blown out on the bat. The waving of the staves occurs again. The Norse will not trade weapons. Perhaps they think such trade to be dangerous or consider their own weapons to be superior. Karlsefni and his fellow Vikings show their shields in reply to the staves, which appear to have been a routine of assuring peaceful contact that the two sides had worked out. The indigenous peoples and Norse exchange pelts and skins for red cloth. All seems to go well.

The narrative outlines a change in relations between the two sides. The territory has a different dynamic:

It so happened, that a bull, which belonged to Karlsefni and his people, ran out from the woods, bellowing loudly. This so terrified the Skrellings, that they sped out to their canoes, and then rowed away to the southward along the coast. For three entire weeks nothing more was seen of them. At the end of this time, however, a great multitude of Skrelling boats was discovered approaching from the south, as if a stream were pouring down, and all of their staves were waved in a direction contrary to the course of the sun, and the Skrellings were all uttering loud cries. Thereupon Karlsefni and his men took red shields and displayed them. The Skrellings sprang from their boats, and they met then, and fought together. ("The Saga” 48)

For the Norse, the bellowing of a bull running suddenly out from the woods "terrified the Skrellings" who fled and rowed away and disappeared for three weeks. This time when they returned, the staves were different and they made loud cries and the Vikings responded with red and not white shields. When the Skrellings leave their boat, a fight ensues. Violence has come to the territory. Later incidents of violence occur after Columbus and John Cabot in the 1490s.

In the battle, as the Viking men fled, Freytis took up the sword of the dead Thorbrand, whose head had been struck in battle: "The Skrellings then approached her, whereupon she stripped down her shift, and slapped her breast with the naked sword. At this, the Skrellings were terrified and ran down to their boats, and rowed away. Karlsefni and his companions, however, joined her and praised her valour." ("The Saga" 48) A woman who is not "hale" defends the men who had fled and this, along with the bellowing of the bull, seems unlikely and perhaps even comic to some. The wounds and deaths are real: "Two of Karlsefni's men had fallen, and a great number of the Skrellings. Karlsefni's party had been overpowered by dint of superior numbers." (48) The violence persists even when they leave the scene of this conflict: 
It now seemed clear to Karlsefni and his people, that although the country thereabouts was attractive, their life would be one of constant dread and turmoil by reason of the [hostility of the] inhabitants of the country, so they forthwith prepared to leave, and determined to return to their own country. They sailed to the northward off the coast, and found five Skrellings, clad in skin-doublets, lying asleep near the sea. There were vessels beside them, containing animal marrow, mixed with blood. Karlsefni and his company concluded that they must have been banished from their own land. They put them to death. (49)

Although the Skrellings had set upon the Vikings, this scene, which seems matter of fact, is chilling. Karlsefni and his Norse companions come upon sleeping indigenous people or Skrellings and, based on their own interpretations and, without further investigation, assume they are exiles and kill them in cold blood when they are not even awake and certainly cannot defend themselves. Violence and conflict occur first in Newfoundland (Vinland) in the New World. After Columbus, the scale of the conflict and killing will be massive and even more egregious, violent and sickening. This is a saga about Canada and part of Canadian literature, history and culture but also of a wider Norse and European culture and of indigenous cultures. It is local and global too.

Here the past and present meet in Newfoundland, a former British colony that became part of another former British (and French) colony, Canada, in 1949. Not only was Newfoundland, after the Norse explored it centuries before Columbus, the first place the English sailed (John Cabot) in 1497 in the wake of Columbus, it became one of the earliest English settlements in the New World along with Jamestown, Plymouth and Boston. Lord Baltimore went there in 1629 but moved his colony to Maryland. On its website, the Canadian government tells about L'Anse aux Meadows National Historic Site:

What happens when a Norse saga comes to life? [...] It wasn't until the 1960s that proof of the Viking presence came, on the tip of Newfoundland's Great Northern Peninsula, with the discovery of a small bronze cloak pin. ("L'Anse")

The Viking past becomes the present in Canada for a national and international audience and visitors, becoming a UNESCO World Heritage Site in 1978. As I am fond of saying, Canada also had a European Middle Ages, so it has the oldest place of European settlement in the Americas. Exploration, sea-faring, archeology and re-enacting or performing the past in the present, historical interpretation, remains, historical reconstruction are all themes of this brief descrip- 
tion about L'Anse aux Meadows National Historic Site, something that UNESCO recognized decades ago for the world.

So the Norse set out West but, unlike Columbus, not in search of Asia. As with Columbus, they discovered that the territories they came across were contested. There were different points of view. The saga describing Vinland, which seems to be in present-day Canada, is Icelandic and Scandinavian as well as Canadian and of Greenland.

\section{Seeking Asia, Asia Seeking: After Columbus}

The expansion of Europe, included voyages to Canada, which is part of the Americas or the New World, and part of globalization, including the European seeking of Asia. That involved peoples who were interconnected globally and these connections complicate any focus on Canada as a nation or on Canadian literature and culture. Canada and its literature and culture occur in a wider and changing context. John Cabot (Giovanni Caboto), Jacques Cartier and others who landed in what is Canada today sought Asia in the wake of Columbus. After all, a suburb of Montreal, Lachine (La Chine) was named after the China that Cartier hoped to discover.

Europe sought Asia by land and then by sea by way of the Americas and by way of Africa. The texts of travelers, explorers and missionaries such as Marco Polo, Columbus, Matteo Ricci, and the images and maps associated with them, show the desire for trade with Asia but also the wish to reach that place by land and water. Yet Columbus, for example, sought Asia but found the New World. In his Journal, there is an early entry, on 13 October 1492, two days after they sighted land, that shows that Columbus hoped he was in Asia: "But, in order not to lose time, I intend to go and see if I can find the island of Cipango." (Columbus 40) Cipango is Japan. They wish to see the mainland of Asia too, and on 30 October 1492, the text describes Columbus: "He says that he must attempt to reach the Gran Can, who he thought was here or at the city of Cathay, which belongs to him, and is very grand, as he was informed before leaving Spain." (63) It is as if Marco Polo and others have helped Columbus dream of China and the imperial center of what was Mongolia, although his geography, as Polo's was, is not definite or certain. The text continues: "The Admiral says that, on the previous Sunday, the 11th of November, it seemed good to take some persons from amongst those at Rio de Mares, to bring to the Sovereigns, that they might learn our language, so as to be able to tell 
us what there is in their lands. Returning, they would be the mouthpieces of the Christians, and would adopt our customs and the things of the faith." (73) This practice of kidnapping predated the westward expansion, but Columbus and later Europeans seek out interpreters, mediators, translators that way. Like Leif Ericson, Columbus makes his motive religious, to convert the people there.

In writing François Ier of France in 1524, Verrazzano describes sailing to what is now the east coast of the United States and sounds like Columbus in his description of the indigenous peoples:

We had seen many people coming to the seashore, but they fled when they saw us approaching; several times they stopped and turned around to look at us in great wonderment. We reassured them with various signs, and some of them came up, showing great delight at seeing us and marveling at our clothes, appearance, and our whiteness; they showed us by various signs where we could most easily secure the boat, and offered us some of their food. (Verrazzano 2)

The special nature of the Europeans in their displacement of wonder or marvel on to the Natives and the use of signs to communicate something that the Norse and Columbus had already employed. Through the Natives, the Europeans wondered at themselves.

Verrazzano also brings a European experience and framework to discuss what is before his eyes in the New World:

They are dark in color, not unlike the Ethiopians, with thick black hair, not very long, tied back behind the head like a small tail. As for the physique of these men, they are well proportioned, of medium height, a little taller than we are. They have broad chests, strong arms, and the legs and other parts of the body are well composed. There is nothing else, except that they tend to be rather broad in the face: but not all, for we saw many with angular faces. They have big black eyes, and an attentive and open look. They are not very strong, but they have a sharp cunning, and are agile and swift runners. From what we could tell from observation, in the last two respects they resemble the Orientals, particularly those from the farthest Sinarian regions. (Verrazzano 2)

Ethiopia and China become the places with peoples whose features, when combined, seem like the peoples the Europeans met on shore. The narrator sees ponytails in the hair, dark skin and agile runners. Africa and Asia are used to explain these people and, implicitly, to compare them with Europeans. Verrazano and his crew think they are near China and India. The European kidnapping of indigenous peoples continues: "We took the boy from the old woman to carry back to France, and we wanted to take the young woman, who was very beautiful and 
tall, but it was impossible to take her to the sea because of the loud cries she uttered. And as we were a long way from the ship and had to pass through several woods, we decided to leave her behind, and took only the boy." (5) This lack of humanity, wrestling children and the young from their families knowingly, like violence itself, makes the Europeans look self-regarding and callous. The narrative continues to compare the people to Asians: "Both men and women have various trinkets hanging from their ears as the Orientals do." (7) Nor do the Europeans always heed the wishes of the indigenous peoples: "Against their wishes, we penetrated two or three leagues inland with XXV armed men, and when we disembarked on the shore, they shot at us with their bows and uttered loud cries before fleeing into the woods." (9) Once more there is conflict between European and indigenous peoples. It does not seem to occur to the Europeans that they might be invading or entering the territory of others who did not invite them.

Verrazzano, along with his contemporaries, is coming to the realization that the New World is not Asia:

My intention on this voyage was to reach Cathay and the extreme eastern coast of Asia, but I did not expect to find such an obstacle of new land as I have found; and if for some reason I did expect to find it, I estimated there would be some strait to get through to the Eastern Ocean. This was the opinion of all the ancients, who certainly believed that our Western Ocean was joined to the Eastern Ocean of India without any land in between. Aristotle supports this theory by arguments of various analogies, but this opinion is quite contrary to that of the moderns, and has been proven false by experience. Nevertheless, land has been found by modern man which was unknown to the ancients, another world with respect to the one they knew, which appears to be larger than our Europe, than Africa, and almost larger than Asia, if we estimate its size correctly. (Verrazzano 10)

Even Verrazzano sought Asia, but he learned when he got to the coast of the present-day Carolinas to New York that the ancients were wrong and that experience tests theory and establishes the truth. Moderns correct the ancients when they erred. Verrazzano is quite clear about what he has uncovered with his crew: "All this land or New World which we have described above is joined together, but is not linked with Asia or Africa (we know this for certain), but could be joined to Europe by Norway or Russia; this would be false according to the ancients." (10) After Columbus, the Europeans went westward to seek Asia and came across the New World. Soon they hoped to find a northwest passage to Asia. 
In the 1530s, Jacques Cartier sailed further north in what is now Canada, areas the English had sailed to about thirty-five years before. The French observed the Natives as earlier explorers had, but they themselves experienced scurvy (see Cartier). Here, very briefly, I wish to emphasize that in a document François Ier declares in 1540 that he has sent "our dear and well loved Jacques Cartier" who "would have discovered" the great "lands of Canada and Hochelaga," achieving a part of Asia on the coast of the West ("envoye nostre cher et bien ame Jacques Cartier, lequel auroict descouvert grand pays des terres de Canada et Ochelaga, faisant un bout de l'Azie du coste de l'Occident"; "Commission" 233). So, like Columbus, Cartier is supposed to be on the edge of Asia and there to convert the indigenous peoples to Christianity. Columbus in the Caribbean, Verrazzano off the east coast of what is the United States and Cartier on the east coast and in the interior of what is now Canada were supposed to seek Asia, encountered the inhabitants of the New World, and often show similar reactions across regions and lands, thereby, in geography and history, weakening any simple sense of culture, nation and literature. The comparative method, including comparative literary, historical and geographical perspectives, shows cultural and textual connections and makes each work and national literature less unto itself.

These travel narratives endure for centuries and the textual complexity of these texts I mention and their editing over time also open a cultural space in which there and here, then and now meet. How does the author survive this mediation, loss, and blurring of editors, translators and others? Some woodcuts were used in the Columbus texts that had been used in the Old World, so spaces and cultures literally get stereotyped, reduced and collapsed while Europe is expanding. Polo, Columbus and Ricci-Italians-all exemplify these dynamics of space and culture. Later scholars, editors and writers discuss these figures so there is an expanding space in time for their reception, reevaluation and the like. Jeannette Armstrong and other Native or indigenous Canadian writers represent Columbus in a new context in recent times. The marking of 1492 in 1592, 1692, 1792, 1892 and 1992 is instructive and crosses boundaries between a major literature and culture (American) with those of a minor one (Canadian) (see Hart, Columbus). 


\section{Natives of the New World}

Points of view of periphery and center also change in the relations between Europeans and Native cultures. At first, Natives find themselves represented in texts or images by Las Casas, Jacques Cartier, Thomas Harriot, John White and others. But even early on, go-betweens like Aguilar, Guerrero, La Malinche, Brûlé and Squanto may be misrepresented. Once more, through these liminal figures, the "national" literatures and cultures blend and breakdown. A modern Mexican mural of the revolutionary period depicts Hernán Cortés and La Malinche, his Nahua or Aztec companion, sitting side by side, hand in hand. A past present (in a national revolution) interprets the figure of conqueror and his interpreter and lover.

Kidnapping is also a central practice and representation in European texts about the indigenous peoples of the New World. The case of Canada and Brazil affected French writing, so center and periphery become triangulated. Jacques Cartier and Jean de Léry wrote texts that created a typology between the Americas, North and South, and Europe, mainly France. These kidnapped Natives, which occur in the texts of Bernal Díaz, Jacques Cartier and others, from various nations became, in the reports of different European cultures, a display of cultural difference, a theatre of the typology of the Old and New World. In the case of Donnacona's sons (in New France or Canada), Taignoagny and Domagaya appear to have appealed in part to the French desire for riches. The representation of Natives in Montaigne was partly a weapon of satire as Tacitus had used the Germans to criticize Rome.

Intertextuality, or the connection among texts, is at play in this time and space of culture and writing (literature) in a mapping that also involves the Caribbean where Columbus had his landfall. So China, Italy, Spain, the Caribbean, the United States and Canada are connected in time and place as the small and large, minor and major form connections that create a wider culture and space in world literature, art and mapping (cartography). Periphery and center modify each other in a constantly changing relation.

Native authors have come to reinterpret the landfall and legacy of Columbus. For instance, Jeannette C. Armstrong's "History Lesson" and Marie Annharte Baker's "Coyote Columbus Café," poems written in Canada by indigenous authors, represent Columbus, who himself had read Marco Polo, and the post-Columbian world as many other Native writers in the Americas all reconfigure the cultural spaces and maps. Armstrong begins her poem on history with a ship: "Out of the 
belly of Christopher's ship / a mob bursts / Running in all directions." (Armstrong 110) Chaos ensues with the arrival of Columbus and the Europeans, a mob bursting everywhere. Baker uses irony to talk about pre-Columbian Natives: "I always forget to mention / we were too good way back when / to be real people before discovery." (Baker 75) The word "discovery" is laden for Native peoples as the Europeans, as François Ier did, employed it from a European point of view. The territories were well inhabited and the inhabitants did not have to discover them. Armstrong and Baker work in a Native tradition that also decenters center and periphery, as do the other texts and figures discussed in a literary and cultural context. A tradition of writers of mixed European and/or African and Native backgrounds also occurs and continues with Derek Walcott and George Elliott Clarke, one from the Caribbean and the other from Canada.

\section{Africans and the New World}

The idea of center and periphery becomes more intricate when examining African as well as Native cultures in the New World and their relations with Europe and European American cultures. In the colonial period boundaries blurred or did not exist between British colonies in what are the territories of Canada and the United States. Phillis Wheatley and Equiano are part of the literature of colonial English/British America and have a relation with England, although being of African descent. They have a connection with writers in Canada, such as Carrie M. Best from Nova Scotia and Dionne Brand, from the Caribbean and writing in Toronto as well as Alice Walker in the United States.

The descendants of Africans in the New World also intricate this notion of identity. Many were forcibly taken as slaves by Europeans who had become part of the Arab-African slave network. The identity of these peoples (sometimes involving converting them from other religions like Islam and erasing or effacing their languages) came under pressure throughout the New World. So the poetry of Phillis Wheatley in the eighteenth century or of Langston Hughes in the twentieth century shows that English in America is not just for people of European descent. The work of Carrie M. Best (1903-2001) says something similar in Canada. Best was a poet, journalist, broadcaster, and much else, suffered and crusaded against racial segregation in New Glasgow, Nova Scotia, and more widely for human rights in Nova Scotia and Canada (see Backhouse; McLeod). As Susanna McLeod says, Best, 
a Canadian of African descent, in her radio show, The Quiet Corner, called on poetic inspiration, European and African, across the border: "Between classical and religious music segments. Best entertained fans by reading the works of American poet Henry Wadsworth Longfellow and African American poet Paul Laurence Dunbar." (McLeod) In her memoir, Best shows the cross-border nature of the African communities in the United States and Canada.

On Sojourner Truth, Best, in her own memoir published in 1977, writes: "The journey of Soujourner Truth, Underground Railroad hero Harriett Tubman, Phyllis Wheatly and other visible minority women of History may appear to be unrelated to a history making journey made over three thousand years ago by another visible minority woman-The Queen of Sheba." (Best, "Sojourner") Best is comparative in finding her examples across the current border with the United States and reaching back to Africa and the Middle East in the Bible. When Wheatley published her book of poems in England in 1773, despite the friction in the colonies, Halifax and Boston were part of the British colonies and there was no national border. After all, as Best also points out in this discussion of Truth, Africans had come in the early seventeenth century and the colonies in what is now Canada split from those that are now part of the United States with the War of Independence (the treaty made that official in 1783).

Discrimination in Canada against Africans and the indigenous populations shared aspects of that phenomenon across the border in the United States. Best herself addresses the injustice of indigenous and African people in the justice system of Nova Scotia when she analyzes the injustice of the case of Donald Marshall:

And I have come to the awful conclusion, as I near the end of my life, that there is absolutely no difference between Donald Marshall, a 17-year old Indian, and Carrie Best, Order of Canada, in the justice system in Nova Scotia. And I say that on the basis of absolute research. [...] If you really want to know what the justice system of Nova Scotia is in relation to blacks and Indians, I will give it to you. I can only say that I have considered that I am not living under British law. I am under the Gag Law of 1885 of the United States of America, this atrocious enactment that said, in essence, that no black has any right that a white person needs to recognize, and they cannot get justice in a court of law. [...] I know you're all familiar with the words of William Lloyd Garrison, the abolitionist in fighting slavery, which is just the mother of racism [...]: "I will not retreat. I will not equivocate. I will not retreat a single inch. And I will be heard." And that is my prayer. It may be my last that I'll ever make in public. But I will die fighting injustice. (Best, "Transcript") 
Best likens the discrimination of British settlers against Natives to that of Blacks and sees Nova Scotia turning its back on British law and adopting discriminatory American law, laws that muzzle Africans and, by extension, indigenous peoples. She quotes Garrison, the famous abolitionist born in Massachusetts, once more crossing another border. This Nova Scotia, this Canada, relates to the United States as well as to Britain and Africa: justice should be for Natives, Africans and Europeans, for all, not just those British settlers who have overseen the courts.

Slavery had been abolished earlier in Canada and in the British Empire than it had been in the United States as a whole (although states such as New York were earlier than the union in that regard), but slavery had existed in Canada and it was partly situational because the French in Canada did not have cotton and sugar cane and other crops that came to rely on slave labor. The French in Canada had Natives integrated into the fur trade, but the French had also passed the Code Noir in the Caribbean setting out a code for Black slaves. North America has a history that had nothing to do with Europe until about a thousand years ago or so. It developed from indigenous culture (the scientists generally seeing Asian roots and routes through migration and Natives maintaining the view of Turtle Island). Africans were brought as slaves soon after Columbus and in 1619 the first slave ship came to the AngloAmerican colonies. Many cultures met and in recent decades multiculturalism has only intensified. English may be the language of the market in English Canada and in the United States but it has many relations there to other languages and cultures. Points of view multiply and that is also centrifugal in relation to languages and literatures. The geography of otherness and the mapping of center and periphery depend on shifting points of view and the movements and meetings of peoples and cultures. Sometimes that meeting is violent. Logic sometimes takes a beating in matters of territory, of hegemony, of conflict, of identity. Making myths and identities can be offensive and defensive at the same time.

\section{Conclusion}

Geography and history affect us past, present and future. Nature and culture are intertwined. In some ways all the water, land and air on earth are connected, and the territories, except for islands, may be divided by geometric lines (as the forty-ninth parallel that divides Canada and the United States on the Great Plains or Prairies). Nations can be artificial and separate people of the same language, culture and even families. 
The internal colonization of European states occurred before and at the same time as external colonization in imperial expansion and, in the case of England/Britain and France, Canada and the United States expanded on their lands. The United States also incorporated Spanish and Russian lands.

Some parts of British North America or Canada were ceded to the United States, so people in those territories have different pasts and presents. European expansion, from the Norse and then the Spaniards onward, changed Europe, the New World and the world generally.

Looking at Canada as a test case and discussing Canadian culture and literature, this article has done so in a comparative and world context. That way we can observe that nation and national literature are centripetal and centrifugal. The relations to neighbors and other states and trading partners within the same language groups and beyond reveal a changing world in time and space. What was peripheral can become central and what was central can become peripheral or just perhaps all places are center and a periphery in some regards. Places can be central and then peripheral and then central for the most part, but quite possibly they are always both to different degrees over time. In some regards, there are no cultures and literatures that are minor or major. They all contribute to the local and the global.

To explore briefly here the idea of interconnectedness, so that Canada and the United States are seen together in a global context in history and now, the article, using a comparative context geographically and between past and present, discussed the Norse exploration of Greenland and Canada; the seeking of Asia, especially after Columbus and Asian contributions to culture and literature in the New World (for instance, as they regard Columbus); the role of indigenous peoples; African contributions, particularly that of Carrie Best. Canada, which had and has, a variety of indigenous peoples, had much to do with Scandinavia, Britain, France, the United States, Asia and Africa, so its culture and literature over time experiences diversity and change.

Small and large, minor and major, comparative and world literatures and cultures have a way of overlapping and intricating, so center and periphery become complicated and even shift in multiple relations and points of view over space and time. Thus, the connection of the central to the peripheral is a fascinating and productive one but with many ways to view it and to make the relations in world literature more complicated than first thought. For instance, Canadian literature is much more than itself. Otherness and mapping create new geographies in culture and literature and in much else. 


\section{WORKS CITED}

Alison, Aurosa. Epistémologie et esthétique de l'espace chez Gaston Bachelard. Milan: Éditions Mimesis, 2019.

Armstrong, Jeannette. "History Lesson." Native Poetry in Canada: A Contemporary Anthology. Ed. Jeannette Armstrong and Lally Grauer. Peterborough, ON: Broadview Press, 2001. 110.

Bachelard, Gaston, La poétique de l'espace. Paris: Presses universitaires de France, 1957. Backhouse, Constance. "I Was Unable to Identify with Topsy: Carrie M. Best's Struggle Against Racial Segregation in Nova Scotia, 1942." Atlantis 22.2 (1998): 16-26.

Baker, Marie Annharte. "Coyote Columbus Café." Native Poetry in Canada: A Contemporary Anthology. Ed. Jeannette Armstrong and Lally Grauer. Peterborough, ON: Broadview Press, 2001. 75.

Baldwin, T. W. William Shakspere's Small Latine \& Lesse Greeke. Urbana, IL: University of Illinois Press, 1944.

Best, Carrie M. "Soujourner Truth." That Lonesome Road. Carrie M Best: A Digital Archive. New Glasgow: n. p., 1977. Access 10. 10. 2021. <http://www.parl.ns.ca/ carriebest/truth.html>

Best, Carrie M. "Transcript of presentation to the Donald Marshall Inquiry, Halifax, N.S. Chairman, Mr. Thomas R. Berger, Nov. 1988." Carrie M Best: A Digital Archive. Access 10. 10. 2021. <http://www.parl.ns.ca/carriebest/marshall.html>

Cartier, Jacques. Relations. Ed. Michel Bideaux. Montréal: Les Presses de l'Université de Montréal, 1986.

Chimisso, Cristina. Gaston Bachelard: Critic of Science and the Imagination. London; New York, NY: Routledge, 2001.

Chimisso, Cristina. "Gaston Bachelard's Places of the Imagination and Images of Space.” Place, Space and Hermeneutics. Ed. Bruce B. Janz. Cham: Springer, 2017. 183-195.

Columbus, Christopher. The Voyage of Christopher Columbus: Columbus' Own Journal of Discovery Newly Restored and Translated. Ed. John Cummins. London: Weidenfeld and Nicholson, 1992.

"Commission délivrée á Cartier (17 octobre 1540)." Relations. By Jacques Cartier. Ed. Michel Bideaux. Montréal: Les Presses de l'Université de Montréal, 1986. 233-235.

Derrida, Jacques. Marges de la philosophie. Paris Éditions de Minuit, 1972.

Derrida, Jacques. Psyché: inventions de l'autre. Paris Galilée, 1987.

Folger, Tim. "Why Did Greenland's Vikings Vanish?” 3. 2017. Smithsonian Magazine. Access 10. 10. 2021. <https://www.smithsonianmag.com/history/why-greenlandvikings-vanished-180962119/>

Hart, Jonathan. Columbus, Shakespeare, and the Interpretation of the New World. New York, NY: Palgrave Macmillan, 2003.

Hart, Jonathan. Empires and Colonies. Cambridge: Polity Press, 2008.

Hart, Jonathan. The Poetics of Otherness: War, Trauma, and Literature. New York, NY: Palgrave Macmillan, 2015.

Hartman, Geoffrey. Scars of the Spirit: The Struggle Against Inauthenticity. New York, NY: St. Martin's Press, 2002.

Kristeva, Julia. Étrangers à nous-mêmes. Paris: Fayard, 1988.

"L’Anse aux Meadows National Historic Site." Last change 15. 8. 2019. Government of Canada. Parks Canada. Access 10. 10. 2021. <https://www.pc.gc.ca/en/lhnnhs/nl/meadows/info> 
Lévinas, Emmanuel. Entre-nous: essais sur le penser-à-l'autre. Paris: Bernard Grasset, 1991.

McIlwraith, Naomi. Kiyâm. Edmonton: Athabasca University Press, 2012.

McLeod, Susanna. "Carrie Best." 31. 1. 2019. The Canadian Encyclopedia. Historica Canada. Access 10. 10. 2021. <https://www.thecanadianencyclopedia.ca/en/article/carrie-best>

Miller, J. Hillis. On Literature. London; New York, NY: Routledge, 2002.

Moreno-Mayar, J. et al. "Terminal Pleistocene Alaskan genome reveals first founding population of Native Americans." Nature 553 (2018): 203-207.

The Oxford English Dictionary. Second edition. Oxford: Oxford University Press, 1989.

Raff, Jennifer. "What the ancient DNA discovery tells us about Native American ancestry." 3. 1. 2018. The Guardian. Accesss 10. 10. 2021. <https://www.theguardian.com/science/2018/jan/03/what-the-ancient-dna-discovery-tells-usabout-native-american-ancestry>

Star, Bastiaan, Barrett, James H., Gondek, Agata T., and Sanne Boessenkool. "Ancient DNA reveals the Chronology of Walrus Ivory Trade from Norse Greenland." Proceedings of the Royal Society B (Biological Sciences) 285.1884 (2018): 1-9.

"The Saga of Eric the Red." The Finding of Wineland The Good. The History of the Icelandic Discovery of America. Ed. and trans. Arthur Middleton Reeves. London: Henry Frowde, 1890. 19-52.

Verrazzano, Giovanni da. "Letter to King Francis 1 of France 8 July 1524 reporting on his voyage to the New World." The Voyages of Giovanni da Verrazzano, 1524-1528. Ed. Lawrence C. Wroth. Transl. Susan Tarrow. New Haven, CT: Yale University Press, 1970.

\section{Določanje centra in periferije ter geografija drugega}

Ključne literatura in geografija / kanadska književnost / center / periferija / kulturna identiteta / drugost / hibridnost / globalizacija

Nekatere književnosti, na primer kanadsko, lahko štejemo za manjše ali manj pomembne, ker Kanada ni svetovna velesila. Toda v resnici so kanadska književnost in druge bodisi velike ali majhne literature del kulturne zgodovine, ki ni le lokalna ali celo nacionalna, ampak mednarodna. Območja kulture in literature se dobesedno ali metaforično spreminjajo skozi čas. V tem članku s primerjalno metodo preučujemo besedila, na primer Sago o Eriku Rdečem in dela Columbusa, Verrazzana, Jeannette C. Armstrong, Marie Annharte Baker in Carrie, da bi prikazali premičnost meja v času in prostoru ter raziskali povezave med kulturami in književnostmi v Kanadi, Evropi, na območju Atlantika ter na mednarodni ravni kot del dolgotrajne globalizacije. Članek dokazuje, 
da hibridnost, ki je posledica medkulturnega stika in kolonizacije, običajno zamegljuje razliko med središčem in obrobjem ter razkriva zgodovinsko fluidnost političnih meja, na katerih temeljijo koncepti nacionalne in svetovne književnosti. Pri tem se osredotoča na to, kako se je Severna Amerika, zlasti Kanada, v zgodovinskem procesu odkrivanja, naselitve in kolonizacije povezala z drugimi deli sveta.

1.01 Izvirni znanstveni članek / Original scientific article

UDK 82.0

821.111(71).09

D0I: https://doi.org/10.3986/pkn.v44.i3.08 